\title{
Mitogenomics and Evolutionary History of Rodent Whipworms (Trichuris spp.) Originating from Three Biogeographic Regions
}

\author{
Jan Petružela ${ }^{1,2, *}$, Alexis Ribas ${ }^{3}$ [D and Joëlle Goüy de Bellocq ${ }^{1,4}$ \\ 1 Institute of Vertebrate Biology, Czech Academy of Sciences, Květná 8, 60365 Brno, Czech Republic; \\ joellegouy@gmail.com \\ 2 Department of Botany and Zoology, Faculty of Science, Masaryk University, Kotlářská 2, \\ 60200 Brno, Czech Republic \\ 3 Section of Parasitology, Department of Biology, Healthcare and the Environment, Faculty of Pharmacy and \\ Food Sciences, University of Barcelona, 08007 Barcelona, Spain; aribas@ub.edu \\ 4 Department of Zoology and Fisheries, Faculty of Agrobiology, Food and Natural Resources, \\ Czech University of Life Sciences Prague, Kamýcká 129, 16521 Prague, Czech Republic \\ * Correspondence: jpetruzela@email.cz
}

Citation: Petružela, J.; Ribas, A.; de Bellocq, J.G. Mitogenomics and Evolutionary History of Rodent Whipworms (Trichuris spp.) Originating from Three Biogeographic Regions. Life 2021, 11, 540. https://doi.org/10.3390/ life11060540

Academic Editor: Cristina Cutillas

Received: 17 April 2021

Accepted: 6 June 2021

Published: 9 June 2021

Publisher's Note: MDPI stays neutral with regard to jurisdictional claims in published maps and institutional affiliations.

Copyright: (c) 2021 by the authors. Licensee MDPI, Basel, Switzerland. This article is an open access article distributed under the terms and conditions of the Creative Commons Attribution (CC BY) license (https:// creativecommons.org/licenses/by/ $4.0 /)$.

\begin{abstract}
Trichuris spp. is a widespread nematode which parasitizes a wide range of mammalian hosts including rodents, the most diverse mammalian order. However, genetic data on rodent whipworms are still scarce, with only one published whole genome (Trichuris muris) despite an increasing demand for whole genome data. We sequenced the whipworm mitogenomes from seven rodent hosts belonging to three biogeographic regions (Palearctic, Afrotropical, and Indomalayan), including three previously described species: Trichuris cossoni, Trichuris arvicolae, and Trichuris mastomysi. We assembled and annotated two complete and five almost complete mitogenomes (lacking only the long non-coding region) and performed comparative genomic and phylogenetic analyses. All the mitogenomes are circular, have the same organisation, and consist of 13 protein-coding, 2 rRNA, and 22 tRNA genes. The phylogenetic analysis supports geographical clustering of whipworm species and indicates that T. mastomysi found in Eastern Africa is able to infect multiple closely related rodent hosts. Our results are informative for species delimitation based on mitochondrial markers and could be further used in studies on phylogeny, phylogeography, and population genetics of rodent whipworms
\end{abstract}

Keywords: Trichuris; whipworms; mitogenomes; comparative genomics; rodents; palearctic; Afrotropical; Indomalayan; phylogenetics

\section{Introduction}

Trichuris is a genus of obligate parasitic nematode which infects a broad range of mammalian hosts, including humans. It is a common caecum parasite with fecal-oral transmission. Depending on the whipworm species in question, the number of hosts ranges from one to several taxonomically related species [1]. The overall degree of host specificity of Trichuris spp. remains an unresolved issue [2]. In humans, whipworms are responsible for the soil-transmitted disease trichuriasis, which manifests itself as gastrointestinal inflammation and can, with heavy infections, cause serious complications, such as rectal prolapse, iron-deficiency anemia, and long-term disabilities (especially in children). Trichuriasis affects over half a billion people annually and is considered to be one of the neglected tropical diseases burdening the developing world [3].

Rodents are the most diverse order of mammals, encompassing around $40 \%$ of all mammalian species, with family Muridae, native to the Old World, leading in both abundance and number of species [4]. Rodents are not only distributed worldwide but also have a rich evolutionary history with evidence of multiple adaptive radiation events $[5,6]$. They are also reservoirs for a plethora of parasitic and pathogenic organisms, some of which 
share a long evolutionary history with their rodent hosts, such as the yeast-like fungus Pneumocystis $[7,8]$. These facts make rodent parasites ideal for studies of host-parasite interactions and co-evolution. Such studies, however, require detailed genomic data.

Whipworms are common parasites of rodents, often showing prevalence over $20 \%$ in wild populations (e.g., 21.1\% in Mus musculus in Central Europe [9], 23 and 38.5\% in Mastomys natalensis in Africa [10,11], or 22\% in Sundamys muelleri from Southeast Asia [12]. The mouse whipworm, Trichuris muris, is extensively used as an animal model of T. trichiura, the human whipworm [13], and is one of the three fully sequenced whipworm genomes together with T. trichiura [14] and T. suis [15].

Despite being one of the most recognized and studied nematodes, there is a lack of genomic data for murine Trichuris species, as the main interest has been with whipworms infecting humans, primates, and farm animals. Hence, there is a number of complete mitochondrial genomes in the literature for species such as sheep, T. ovis [16], or pigs, T. suis [17], but there is only one described mitochondrial genome for murine Trichuris, namely T. muris [18]. From these first mitogenomes, some peculiarities are already apparent. They exhibit a high degree of amino-acid divergence between species, unlike other nematode genera, such as Ancylostoma spp. [19,20] or Toxocara spp. [21]. They also have the ATP8 gene, which is absent in the rest of Nematoda (except early diverging Trichinella) [16,22]. As with other Nematoda, the whipworm mitogenomes are strongly AT biased.

Whipworm genetic data have been restricted to not only a few hosts but also restricted in geographic representation. This is unfortunate, since whipworms are often difficult to distinguish by morphology alone, and genetic data are helpful to reveal cryptic diversity $[10,23,24]$. In fact, molecular methods have become an increasingly important tool for completing the morphological description of different whipworm species, e.g., T. arvicolae [24], T. mastomysi and T. carlieri [10], T. cutillasae [25], or, most recently, T. cossoni [12]. Genetic studies based on nuclear markers, such as ITS-1, ITS-2, or 5.8S, have proven useful to distinguish closely related whipworm species $[1,25,26]$. However, the mitochondrial genome allows study of long non-recombining sequences with high substitution rates compared to nuclear. In addition, nematode mitogenomes are useful phylogenetic tools due to their diverse structure and gene-order rearrangements [22]. With the advent of next-generation sequencing, it has become increasingly cost-effective to sequence full mitogenomes. Because of this, multiple studies have now incorporated full mitogenomes to address the questions of whipworm phylogenetics or species delineation $[16,17,27]$.

In this study, we characterised and performed a comparative genomic analysis of seven Trichuris mitochondrial genomes from different rodent species. Three of our samples are previously described whipworm species, Trichuris mastomysi [28], Trichuris arvicolae [24], and Trichuris cossoni [12]. Our whipworm samples cover three biogeographic regions (see Table 1): four species come from Afrotropical Muridae rodents, two species from Indomalayan Muridae rodents, and the remaining species from a Cricetidae rodent from the Palaearctic region. We also included the mitochondrial genome of the palearctic T. muris in our comparative analyses. The murid hosts sampled in our study came from three tribes (Murini, Rattini, and Praomyini-see Table 1). We then investigated the evolutionary history of the rodent Trichuris mitogenomes. The distribution of Trichuris samples in terms of rodent-host phylogeny and biogeographic origins allow us to evaluate which between these two factors plays the more dominant role in shaping the evolutionary history of rodent whipworms. 
Table 1. Samples and host organisms used in the present study. Abbreviations: Gb. AN, GenBank accession number; Lat., latitude; Lon., longitude.

\begin{tabular}{|c|c|c|c|c|c|c|c|c|c|}
\hline $\begin{array}{l}\text { Trichuris } \\
\text { Species }\end{array}$ & Host & $\begin{array}{c}\text { Rodent } \\
\text { Family/Tribe }\end{array}$ & $\begin{array}{c}\text { Biogeographic } \\
\text { Region }\end{array}$ & Gb. AN & $\begin{array}{l}\text { Gb. AN } \\
\text { (Host) }\end{array}$ & Year & Country & Lat. & Lon. \\
\hline $\begin{array}{l}\text { Trichuris } \\
\text { arvicolae }\end{array}$ & $\begin{array}{l}\text { Microtus } \\
\text { arvalis }\end{array}$ & Cricetidae/Arvicolini & Palaearctic & MZ229684 & KX380038 & 2014 & $\begin{array}{c}\text { Czech } \\
\text { Republic }\end{array}$ & 50.1327 & 12.6156 \\
\hline $\begin{array}{l}\text { Trichuris } \\
\text { sp. }\end{array}$ & $\begin{array}{l}\text { Praomys } \\
\text { misonnei }\end{array}$ & Muridae/Praomyni & Afrotropical & MZ229689 & MZ222133 & 2010 & Kenya & 0.2382 & 34.8647 \\
\hline $\begin{array}{l}\text { Trichuris } \\
\text { sp. }\end{array}$ & $\begin{array}{c}\text { Mastomys } \\
\text { erythroleu- } \\
\text { cus }\end{array}$ & Muridae/Praomyni & Afrotropical & MZ229686 & MZ222134 & 2012 & Ethiopia & 4.9624 & 38.2068 \\
\hline $\begin{array}{c}\text { Trichuris } \\
\text { sp. }\end{array}$ & $\begin{array}{c}\text { Mus } \\
\text { mahomet }\end{array}$ & Muridae/Murini & Afrotropical & MZ229688 & MN223610 & 2012 & Ethiopia & 6.8638 & 37.7629 \\
\hline $\begin{array}{l}\text { Trichuris } \\
\text { mastomysi }\end{array}$ & $\begin{array}{l}\text { Mastomys } \\
\text { natalensis }\end{array}$ & Muridae/Praomyni & Afrotropical & MZ229690 & MK454444 & 2016 & Tanzania & $\begin{array}{c}- \\
8.0383 \\
\end{array}$ & 36.8444 \\
\hline $\begin{array}{l}\text { Trichuris } \\
\text { sp. }\end{array}$ & Mus caroli & Muridae/Murini & Indomalayan & MZ229687 & KJ530558 & 2016 & Lao PDR & 18.3701 & 102.4998 \\
\hline $\begin{array}{c}\text { Trichuris } \\
\text { cossoni }\end{array}$ & $\begin{array}{c}\text { Bandicota } \\
\text { indica }\end{array}$ & Muridae/Rattini & Indomalayan & MZ229685 & HM217476 & 2016 & Lao PDR & 18.3412 & 102.4782 \\
\hline
\end{tabular}

\section{Materials and Methods}

\subsection{Sampling, DNA Extraction, and Sequencing}

We used 7 Trichuris spp. (see Table 1 for sample information) preserved in $70 \%$ ethanol collected during previous studies on the evolutionary history, taxonomy, and ecology of rodents and their associated parasites and pathogens in Asia, Africa, and Europe $[7,12,29]$. Three of these samples were identified based on their morphological characteristics as T. mastomysi, recovered from the Natal multimammate mouse, Mastomys natalensis, from Tanzania; T. arvicolae, recovered from the common vole, Microtus arvalis, in the Czech Republic; and T. cossoni, recovered from the greater bandicoot rat, Bandicota indica in Laos [10,12,24]. DNA was extracted using Invisorb Spin Forensic kit (Stratec, Berlin, Germany) following the manufacturer instructions (but without using the carrier RNA). For 3 of our samples for which we obtained a very low amount of DNA after Qubit (Life Technologies, Eugene, OR, USA) measurement $(<1 \mathrm{ng} / \mu \mathrm{L})$, we performed a whole genome amplification (WGA) step using the Illustra Ready-To Go GenomiPhi V3 DNA amplification kit (GE Healthcare, Chalfont, UK) to increase the amount of DNA before library preparation. Trichuris DNA (WGA or not) was equimolarly pooled with DNA from another nematode belonging to the family Oxyuridae, and libraries were prepared using the KAPA HyperPrep kit (Roche, KAPA, Cape Town, South Africa). A pool of 24 dual indexed libraries (with 7 containing the Trichuris samples of this study and 17 additional ones from a wider nematode mitochondrial study) were sequenced using Illumina MiSeq platform and v2 chemistry (San Diego, CA, USA) (i.e., $2 \times 250$ bp paired-end reads) at the CEITEC Genomics Core Facility (Brno, Czech Republic). After de novo assembly of the mitogenomes, we found that the long non-coding region (NCR-L) was missing for all samples. So, for two samples for which we had some DNA left, i.e., Trichuris samples from Mus caroli and Mus mahomet, we characterised the variable region NCR-L by Sanger sequencing with primers designed in the surrounding NAD1 and NAD2 genes.

\subsection{Genetic Characterisation of Rodent Hosts}

For 2 host samples for which we had access to tissues, we confirmed the field identification by cytochrome $b$ (CYTB) genotyping. We amplified the CYTB gene with primers H15915 and L14723 [30] using the Multiplex PCR kit (Qiagen, Hilden, Germany) in a final volume of $15 \mu \mathrm{L}$ and using $1 \mu \mathrm{L}$ of extracted DNA. Amplicons were Sanger-sequenced at 
Eurofins Genomics (Germany). For the Asiatic rodent samples, we did not have access to tissue or DNA, but a metagenomic study of the saliva sample from the same Mus specimen allowed us to retrieve a 300 nucleotide-long contig that BLASTed 100\% with Mus caroli R5231 CYTB (GenBank AN: KJ530558). We thus used the complete CYTB from R5231 in the subsequent analysis. The CYTB of the Mastomys natalensis individual host of T. mastomysi was sequenced in a previous study (GenBank AN: MK454444) [31].

\subsection{Mitogenome Assembly and Comparative Analyses}

Obtained reads were quality checked using Fastqc software v0.11.5 [32] and trimmed using Skewer v0.2.2 [33]. The assembly was performed by Spades v3.12.0 [34] and the contigs corresponding to the mitochondrial genome identified with a pipeline consisting of Diamond v0.8.24.86 [35], Blast v2.5.0 [36], and BlobTools v0.9.19.4 [37] software. The two full mitogenome assemblies from $M$. caroli and M. mahomet whipworms were finalised in Geneious 11.1.5 after adding the sequences of the NCR-L variable region obtained by Sanger sequencing. Almost complete $(\mathrm{N}=5)$ and complete $(\mathrm{N}=2)$ assembled mitogenomes were analysed in Geneious and tools included therein. We added the mitogenome of T. muris (NC_028621) for the purpose of comparative genome analyses.

The sequences were aligned by Mauve genomic aligner [38]. The open reading frames were analysed with the Geneious ORF Tool using the invertebrate mitochondrial code and compared to the annotated genome of T. muris. Pairwise mean nucleotide and aminoacid identities were calculated for homologous genes. Putative secondary structures of 22 tRNA genes were identified using software ARWEN [39]. As an independent check, we compared these annotations to the ones obtained using the MITOS pipeline web server [40]. Additional statistical analysis was performed using a custom Python 3.6 script [41] Python Software Foundation, Python Language Reference, version 3.6, using packages Biopython 1.75 [42], Numpy 1.16 [43], and Matplotlib 3.3.4 [44]. We used a sliding-window approach with $1000 \mathrm{bp}$ windows and $25 \mathrm{bp}$ steps to compare GC contents and mean pairwise differences between each sample pair.

\subsection{Phylogenetic Analysis}

For the purpose of phylogenetic analysis, the mitogenomes of T. ovis (NC_018597), T. trichiura (NC_017750), and Trichinella spiralis (NC_002681) were added to the alignment and used as outgroup samples. jModelTest v2.1.10 [45] was used to test the substitution models. Phylogenetic analysis was performed via Bayesian inference (BI) conducted in MrBayes v3.2.6 [46] and complemented by a maximum likelihood phylogenetic analysis conducted in RaxML v8.2.12 [47]. The whole genome alignments were used for the phylogenetic analyses. GTR+G was used as substitution model. The analysis was performed using four independent Markov chain runs for 4,000,000 MCMC generations, sampling every 2000 th generation. The first $25 \%$ of samples were discarded as burn-in. To compare the level of consistency between the two phylogenetic methods, we first checked the topologies for any inconsistencies and then plotted the individual values of pairwise differences between same sample pairs given by the different methods against each other. This comparison was performed to compare the difference between branch lengths as given by the two methods of phylogenetic analysis.

Only the Bayesian inference analysis using MrBayes was performed for the host samples. We used similar settings for host CYTB sequence analysis, with Rhizomys pruinosus (MH189045) used as outgroup. For host species for which we did not have access to tissue, we used the following GenBank sequences: Bandicota indica: HM217476, Microtus arvalis: KX380038, Mus musculus: KX790793, and Mus mahomet: MN223610. The only host/parasite difference in the MrBayes settings was the choice of JC96 as the host substitution model. 


\section{Results}

\subsection{Genomic Features and Annotations}

All assemblies were cut in the NCR-L, which uniformly had the lowest coverage. We completed this region for sample LO613 obtained from Mus caroli and ETH232 obtained from Mus mahomet via Sanger sequencing. However, the NCR-L was missing from the other assembled sequences. The two complete mitogenomes, T. sp. ex Mus caroli and T. sp. ex Mus mahomet (Figure 1), had lengths 14,165 bp and 14,100 bp, respectively (see Table 2 for comparison and Table S1 for comparison of the incomplete genomes). All mitogenomes contained 13 protein coding genes (PCGs) (COX1-COX3, NAD1-NAD6, NAD4L, ATP6, ATP8, and CYTB), with NAD5 being the longest and ATP8 the shortest in all samples, 2 rRNA genes, and 22 tRNA genes (except T. cossoni, see below). Four PCGs (NAD2, NAD5, NAD4, and NAD4L) and 10 tRNA genes (tRNA-Met, tRNA-Phe, tRNA-His, tRNA-Arg, tRNA-Pro, tRNA-Trp, tRNA-Ile, tRNA-Gly, tRNA-Cys, and tRNA-Tyr) were encoded by the L-strand, with the rest being encoded by the H-strand. The NCR-L was located between NAD1 and tRNA-Lys, while the short non-coding region (NCR-S) was found between NAD3 and tRNA-Ser(UCN) (Figure 1). These findings are consistent with published literature on Trichuris mitogenomes. Genes NAD1 and NAD2 were incomplete, and the tRNA-Lys sequence was missing in T. cossoni ex Bandicota indica, as these lie in the immediate vicinity of the missing NCR-L region. In the same sample, the NAD4L gene was abnormally longer (336) than the rest (249-252 bp), with an overlap with NAD4 gene. The reason is a mutation in position 7427 with A replacing $T$ and changing the function of an original stop codon. We checked the trimmed reads to rule out an assembly error. For the seven studied mitogenomes, the average nucleotide frequencies were $34.6 \% \mathrm{~A}, 12.3 \%$ $\mathrm{C}, 13.9 \% \mathrm{G}$, and $37.2 \% \mathrm{~T}$. The nucleotide composition was strongly biased towards $\mathrm{A}+\mathrm{T}$ $(73.3 \%)$, with $\mathrm{T}$ being the most favoured and $\mathrm{C}$ being the least favoured nucleotide.

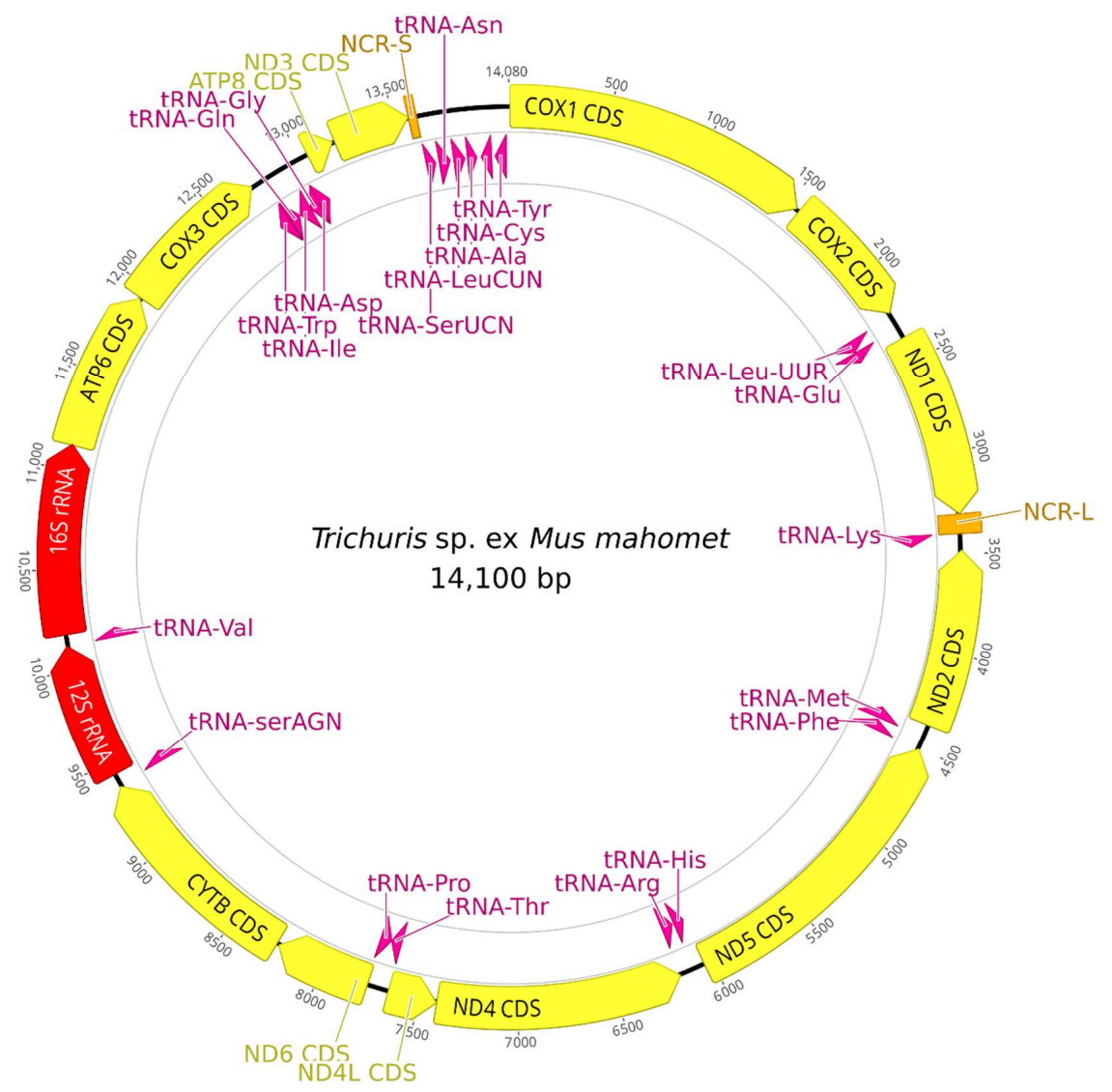

Figure 1. Structure of mitogenome for T. sp. ex Mus mahomet. 
Table 2. Mitogenome organisation of T. sp. ex Mus caroli and T. sp. ex Mus mahomet. Abbreviations: ini, initiation; ter, termination.

\begin{tabular}{|c|c|c|c|c|c|c|c|c|}
\hline \multirow[t]{3}{*}{ Gene/Region } & \multicolumn{4}{|c|}{ Position in Genome } & \multirow[t]{2}{*}{ Strand } & \multicolumn{2}{|c|}{ Ini/Ter Codons } & \multirow[t]{3}{*}{ Anticodon } \\
\hline & \multicolumn{2}{|c|}{ T. sp. ex Mus mahomet } & \multicolumn{2}{|c|}{ T. sp. ex Mus caroli } & & \multirow[t]{2}{*}{$\begin{array}{c}\text { T. sp. ex Mus } \\
\text { mahomet }\end{array}$} & \multirow[t]{2}{*}{$\begin{array}{c}T . \text { sp. ex } \\
\text { Mus caroli }\end{array}$} & \\
\hline & Position & Length & Position & Length & & & & \\
\hline COX1 & $1-1545$ & 1545 & $1-1545$ & 1545 & $\mathrm{H}$ & ATG/TAG & ATG/TAA & \\
\hline COX2 & $1562-2239$ & 678 & $1556-2236$ & 681 & $\mathrm{H}$ & ATG/ & AA & \\
\hline $\begin{array}{l}\text { tRNA-Leu- } \\
\text { UUR }\end{array}$ & $2253-2317$ & 65 & $2258-2326$ & 69 & $\mathrm{H}$ & & & TAA \\
\hline tRNA-Glu & $2321-2383$ & 63 & 2349-2414 & 66 & $\mathrm{H}$ & & & TTC \\
\hline NAD1 & $2401-3303$ & 903 & $2428-3330$ & 903 & $\mathrm{H}$ & ATT/TAG & ATA/TAG & \\
\hline NCR-L & $3304-3403$ & 100 & $3331-3412$ & 82 & & & & \\
\hline tRNA-Lys & $3404-3466$ & 63 & $3413-3472$ & 60 & $\mathrm{H}$ & & & TTT \\
\hline NAD2 & $3484-4377$ & 894 & $3485-4378$ & 894 & $\mathrm{~L}$ & ATA/ & AA & \\
\hline tRNA-Met & $4378-4439$ & 62 & $4379-4442$ & 64 & $\mathrm{~L}$ & & & CAT \\
\hline tRNA-Phe & $4450-4506$ & 57 & $4447-4506$ & 60 & $\mathrm{~L}$ & & & GAA \\
\hline NAD5 & $4507-6043$ & 1537 & $4520-6059$ & 1542 & $\mathrm{~L}$ & ATC/TAA & ATA/TAA & \\
\hline tRNA-His & $6044-6100$ & 57 & $6060-6115$ & 56 & $\mathrm{~L}$ & & & GTG \\
\hline tRNA-Arg & $6111-6172$ & 62 & 6130-6196 & 67 & $\mathrm{~L}$ & & & TCG \\
\hline NAD4 & $6171-7406$ & 1236 & $6195-7424$ & 1230 & $\mathrm{~L}$ & ATG/TAA & ATT/TAA & \\
\hline NAD4L & $7406-7654$ & 249 & $7451-7702$ & 252 & $\mathrm{~L}$ & ATT $/$ & $\mathrm{AA}$ & \\
\hline tRNA-Thr & $7656-7712$ & 57 & 7705-7757 & 53 & $\mathrm{H}$ & & & TGT \\
\hline tRNA-Pro & $7714-7772$ & 59 & 7763-7818 & 56 & $\mathrm{~L}$ & & & TGG \\
\hline NAD6 & $7765-8247$ & 483 & $7811-8286$ & 476 & $\mathrm{H}$ & ATA/TAA & ATT/TAA & \\
\hline СYТВ & $8258-9370$ & 1113 & $8312-9424$ & 1113 & $\mathrm{H}$ & ATG/TAA & ATG/TAG & \\
\hline $\begin{array}{l}\text { tRNA- } \\
\text { serAGN }\end{array}$ & $9381-9436$ & 56 & $9430-9484$ & 55 & $\mathrm{H}$ & & & TCT \\
\hline 12S rRNA & $9437-10,119$ & 683 & $9484-10,193$ & 710 & $\mathrm{H}$ & & & \\
\hline tRNA-Val & $10,121-10,173$ & 53 & $10,193-10,248$ & 56 & $\mathrm{H}$ & & & TAC \\
\hline 16S rRNA & $10,176-11,128$ & 953 & $10,251-11,212$ & 962 & $\mathrm{H}$ & & & \\
\hline ATP6 & $11,126-11,935$ & 811 & $11,222-12,037$ & 816 & $\mathrm{H}$ & ATA/TAA & ATG/TAG & \\
\hline COX3 & $11,939-12,718$ & 780 & $12,044-12,829$ & 786 & $\mathrm{H}$ & ATG/ & AA & \\
\hline tRNA-Trp & $12,723-12,788$ & 66 & $12,829-12,890$ & 62 & $\mathrm{~L}$ & & & TCA \\
\hline tRNA-Gln & $12,792-12,847$ & 56 & $12,898-12,952$ & 55 & $\mathrm{H}$ & & & TTG \\
\hline tRNA-Ile & $12,855-12,919$ & 65 & $12,959-13,023$ & 65 & $\mathrm{~L}$ & & & GAT \\
\hline tRNA-Gly & $12,920-12,976$ & 57 & $13,031-13,088$ & 58 & $\mathrm{~L}$ & & & TCC \\
\hline tRNA-Asp & $12,977-13,037$ & 61 & $13,098-13,154$ & 57 & $\mathrm{H}$ & & & GTC \\
\hline ATP8 & $13,038-13,178$ & 141 & $13,155-13,307$ & 153 & $\mathrm{H}$ & ATA/TAG & ATT/TAA & \\
\hline NAD3 & $13,187-13,528$ & 342 & $13,307-13,648$ & 342 & $\mathrm{H}$ & ATT/TAG & ATT/TAA & \\
\hline NCR-S & $13,529-13,635$ & 107 & $13,649-13,761$ & 113 & & & & \\
\hline $\begin{array}{l}\text { tRNA- } \\
\text { SerUCN }\end{array}$ & $13,636-13,688$ & 53 & $13,762-13,815$ & 54 & $\mathrm{H}$ & & & TGA \\
\hline tRNA-Asn & $13,706-13,766$ & 61 & $13,814-13,882$ & 69 & $\mathrm{H}$ & & & GTT \\
\hline $\begin{array}{l}\text { tRNA- } \\
\text { LeuCUN }\end{array}$ & $13,788-13,853$ & 66 & $13,889-13,951$ & 63 & $\mathrm{H}$ & & & TAG \\
\hline tRNA-Ala & $13,865-13,919$ & 55 & $13,967-14,020$ & 54 & $\mathrm{H}$ & & & TGC \\
\hline tRNA-Cys & $13,945-14,001$ & 57 & $14,030-14,088$ & 59 & $\mathrm{~L}$ & & & GCA \\
\hline tRNA-Tyr & $14,020-14,076$ & 57 & $14,098-14,155$ & 58 & $\mathrm{~L}$ & & & GTA \\
\hline
\end{tabular}

All PCGs used ATG, ATA, TTG, or ATT as their initiation codon. All PCGs except for NAD5 had complete termination codons. In the whole dataset, only COX2 and COX3 (and possibly NAD4, but this could not be inferred due to the missing sequence in $T$. cossoni sample) had initiation and termination codons identical across all samples. Most of the 22 tRNA genes could be folded into standard secondary structures. The length of tRNA genes ranged from 45 to $94 \mathrm{bp}$, consistent with other literature on Trichuris mitogenomes, and the tRNA-Ser lacked D-arm and loop [16]. In each genome, the 12S-rRNA gene was located between tRNA-Ser(AGN) and tRNA-Val, while 16S-rRNA gene was found between tRNA-Val and ATP6 gene. There were no differences in tRNA anticodons across the 
samples. The position of NCR-L could be inferred from the assembly even in those samples, being between the genes NAD1 and tRNA-Lys. However, very limited conclusions about the base composition in said region could be drawn, since the coverage of NCR-L was either too low or non-existent in the five samples mentioned. The NCR-S was located between NAD3 and tRNA-SerUCN.

\subsection{Comparative Genomic Analyses}

The reference genome of T. muris was added to our samples for the analyses within this section. For summary statistics, see Table 3. The sequence divergences between the genomes were substantial, ranging from $2.2 \%$ to $34.5 \%$, with average pairwise divergence being 21.7\% (Figure 2). The number and order of mitochondrial genes (13 PCGs, 22 tRNA genes, and 2 rRNA genes) and non-coding regions was identical across all studied mitogenomes. The mean pairwise divergence between the samples was $24.7 \%$, with 7320 invariant sites across the whole dataset (45.8\%). The magnitude of nucleotide sequence divergence in each gene ranged from $15 \%$ in COX1, being the most conserved gene, to $32.8 \%$ in ATP8, being the least conserved one. Amino-acid sequences were also compared. There were a total of 1361 amino-acid substitutions across all individual proteins without NAD1 and NAD2. The mean pairwise difference ranged from $7.3 \%-38 \%$, with COX1 being the most and ATP8 the least conserved protein. There were no marked differences in GC content across our samples (Figure 3). Both non-coding regions were heavily AT biased (AT percentages $78.6 \%$ for NCR-L and $80.2 \%$ for NCR-S). Although the information about NCR-L came from two samples only, these were very similar to the NCR-L of T. muris both in length (82 bp in T. sp. ex Mus caroli and 100 bp in T. sp. ex Mus mahomet vs. 112 bp in T. muris) and composition (GC content $21.4 \%$ average in our samples vs. $19.6 \%$ in T. muris). The average length of NCR-S (107.4 bp in our samples vs. $106 \mathrm{bp}$ in T. muris) and GC content was similar to the T. muris (19.8\% average in our samples vs. $20.8 \%$ in T. muris).

Table 3. Summary of differences in nucleotide sequences and predicted amino-acid sequences. * statistics for NAD1 and NAD2 were computed excluding the sample of T. cossoni, which had incomplete sequences at these sites. Abbreviations: Nuc, nucleotide; ini, initiation; ter, termination. ${ }^{* *}$ statistics for NCR-L were computed using only samples of T. sp. ex Mus mahomet and T. sp. ex Mus caroli.

\begin{tabular}{|c|c|c|c|c|c|c|}
\hline Gene/Region & $\begin{array}{l}\% \text { of Invariant } \\
\text { Sites (nuc) }\end{array}$ & $\begin{array}{l}\text { Mean Pairwise } \\
\text { diff. (nuc) }\end{array}$ & $\begin{array}{l}\text { Mean Pairwise } \\
\text { Difference (aa) }\end{array}$ & $\%$ GC & $\begin{array}{l}\text { Mean Nucleotide } \\
\text { Length }\end{array}$ & Ini/Ter Codons \\
\hline COX1 & 66.7 & 15.00 & 7.3 & 33.4 & 1546 & variable \\
\hline COX2 & 58.3 & 18.60 & 15.4 & 32.4 & 678 & ATG/TAA \\
\hline NAD1 * & 59.5 & 15.5 & 17.7 & 36.8 & 903 & variable \\
\hline NCR-L ** & 56.0 & 44.0 & - & 21.4 & 96.5 & - \\
\hline NAD2 * & 54 & 17.3 & 24.3 & 37.1 & 894 & ATA/TAA \\
\hline NAD5 & 59.4 & 17.80 & 24.5 & 25.3 & 1538 & variable \\
\hline NAD4 & 48.8 & 22.40 & 21.3 & 24.6 & 1203 & variable \\
\hline NAD4L & 51.8 & 20.90 & 24 & 25.7 & 250 & variable \\
\hline NAD6 & 45.8 & 24.50 & 29.2 & 23.9 & 481 & variable \\
\hline CYTB & 59.5 & 17.70 & 16.5 & 28.6 & 1116 & variable \\
\hline 12S rRNA & 57.9 & 17.20 & - & 24.2 & 688 & - \\
\hline 16S rRNA & 55.6 & 19.70 & - & 22.7 & 953 & - \\
\hline ATP6 & 45.0 & 24.10 & 28 & 22.4 & 809 & variable \\
\hline COX3 & 52.8 & 20.60 & 15.4 & 28.1 & 782 & ATG/TAA \\
\hline ATP8 & 31.3 & 32.30 & 38 & 23.7 & 143 & variable \\
\hline NAD3 & 60.8 & 16.8 & 16.6 & 22.6 & 342 & variable \\
\hline NCR-S & 17.6 & 38.4 & - & 19.8 & 107.4 & - \\
\hline
\end{tabular}




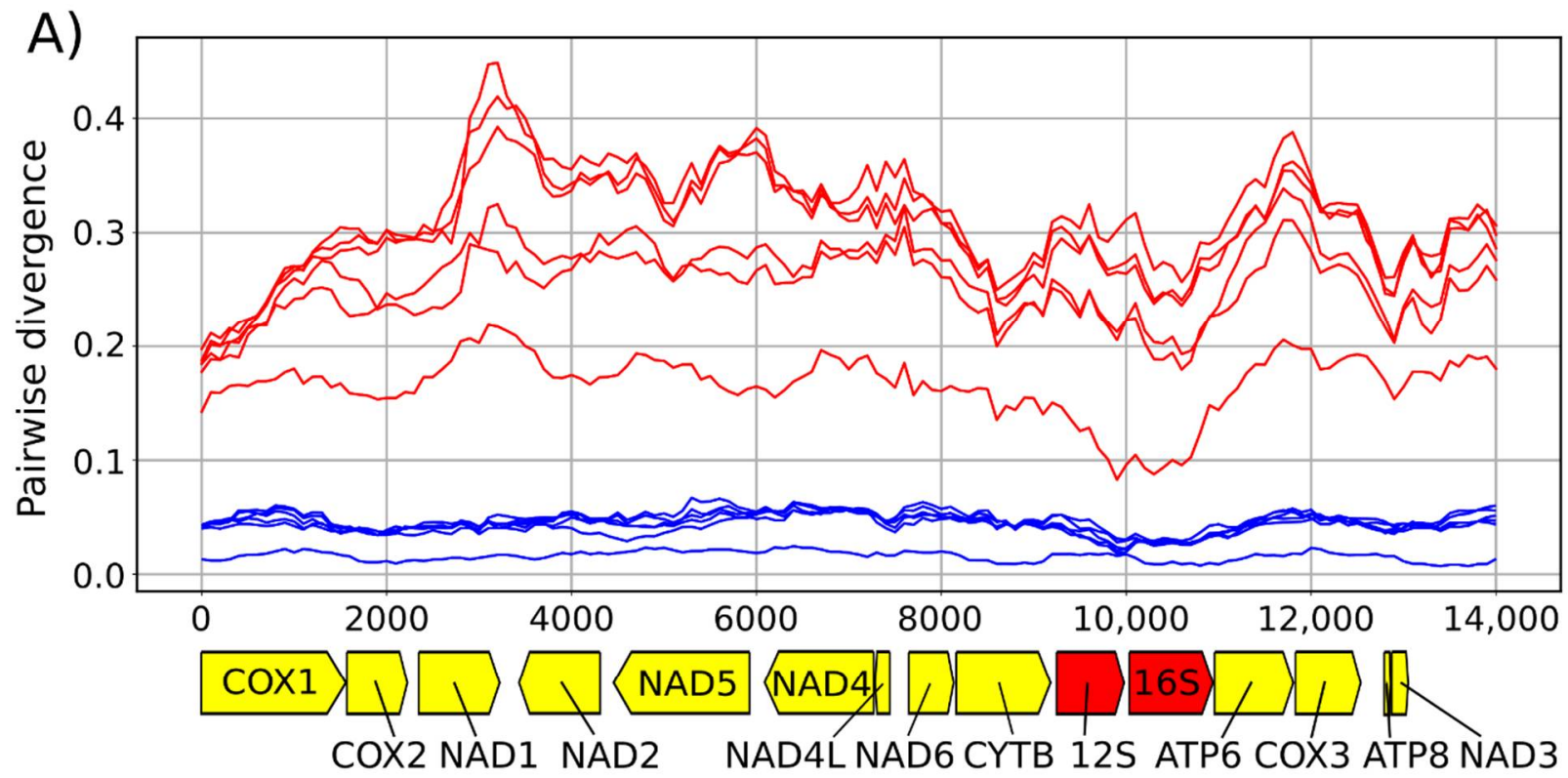

B) Position in genome (bp)

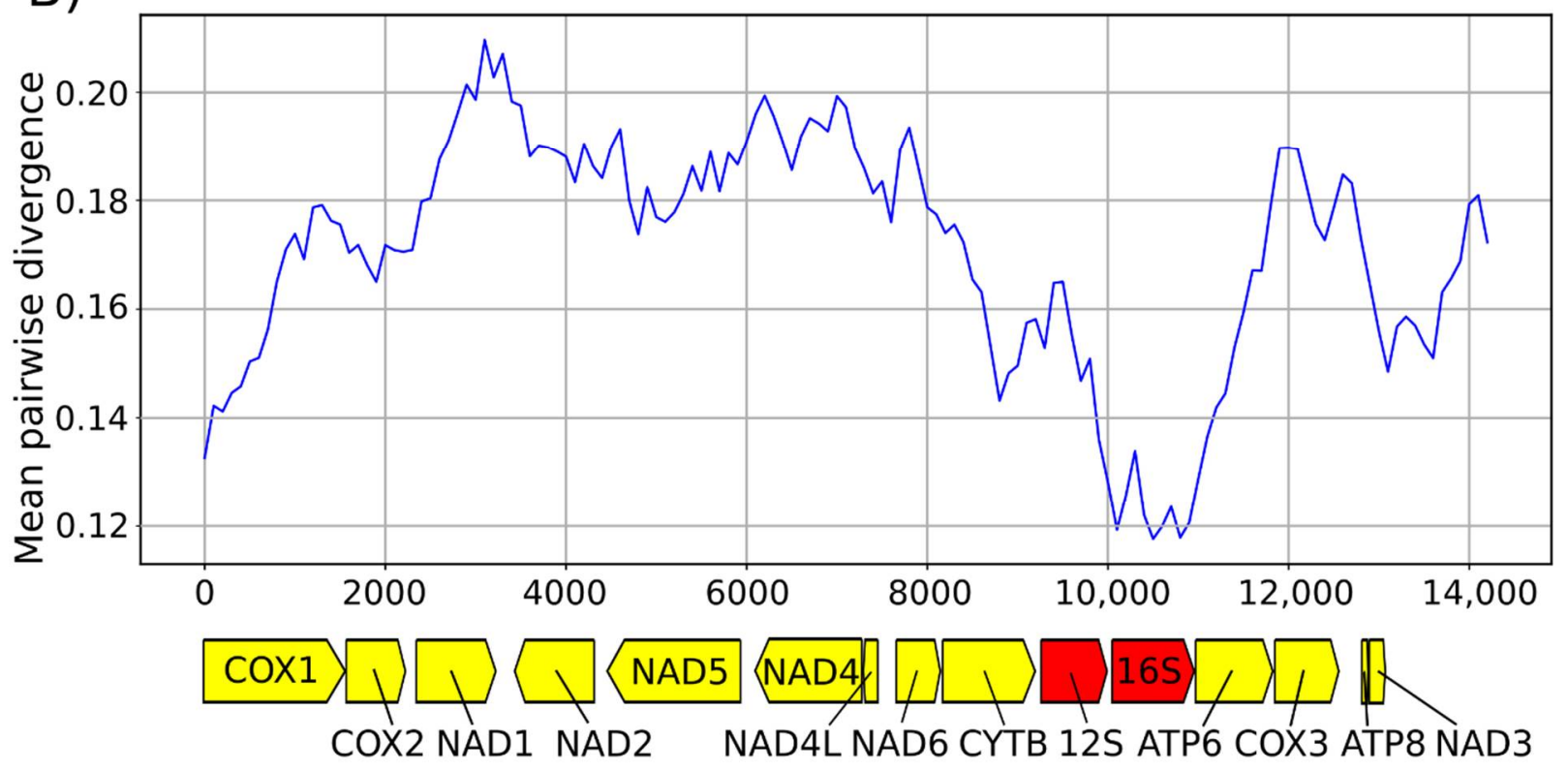

Position in genome (bp)

Figure 2. (A) Individual pairwise distances for all samples measured by using a sliding window of $1000 \mathrm{bp}$ with $100 \mathrm{bp}$ steps. The blue lines represent the distances among samples from the Afrotropical region only; the red lines represent the rest of the cal region and samples from elsewhere. (B) Mean pairwise distance for all samples measured by using a sliding window of $1000 \mathrm{bp}$ with $100 \mathrm{bp}$ steps. 


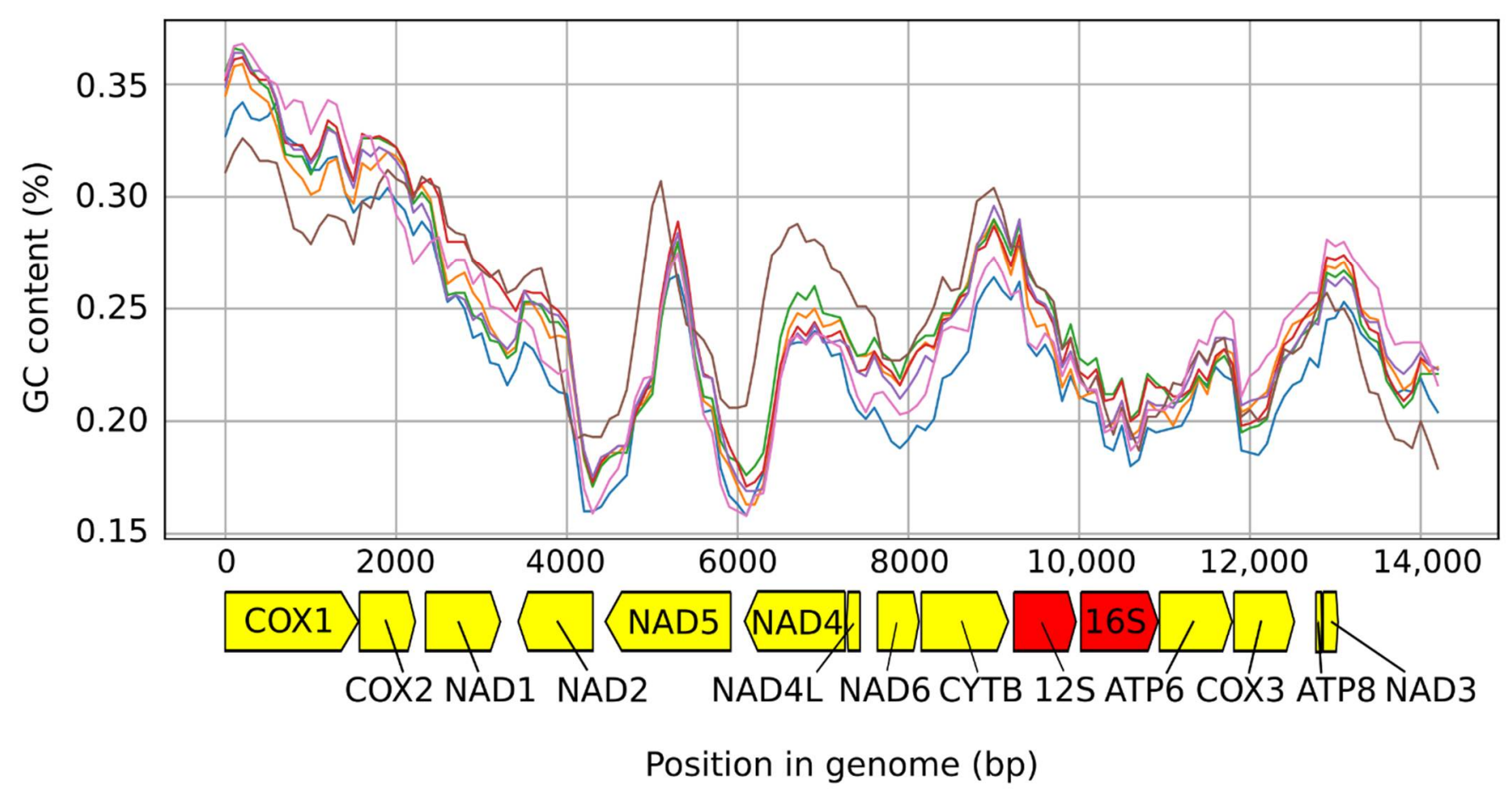

Figure 3. Mean GC content for all samples measured by using a sliding window of 1000 bp with 100 bp steps.

\subsection{Phylogenetic Analysis}

Both maximum likelihood and Bayesian inference analyses gave the same phylogenetic topology (Figure 4) and very similar branch lengths. The difference between individual pairwise divergences for each method of phylogenetic analysis was low, ranging from $0-0.25$, with average difference of 0.056 (for more details, see Figure S1). The phylogenetic analyses revealed that the Trichuris derived from Afrotropical rodents clustered into a single haplogroup (Figure 4). Samples from this haplogroup had a mean pairwise difference at $4.4 \%$, with 12,917 sites being completely invariant (91.5\%). Trichuris from Palearctic rodents, $M$. arvalis (Czech Republic) and M. musculus, formed a sister group to this haplogroup. T. sp. ex Mus caroli (Laos) was basal to all other rodent derived Trichuris, with T. cossoni ex Bandicota indica (Laos) being the second most basal sample. The samples from Afrotropical and Palearctic regions formed two highly supported monophyletic haplogroups, while the Indomalayan samples did not form a monophyletic group. The divergence (per Bayesian inference analysis) between whipworms found in ungulates (T. ovis) and whipworms found in rodents was of the same order of magnitude than between two rodent pinworms: The pairwise difference between T. sp. ex Mus caroli and T. muris was $33.1 \%$, while the difference between it and the T. ovis was $36.7 \%$. The phylogenetic pattern strongly supports geographical clustering of rodent-derived Trichuris, with no clear evidence of codivergence between the host and parasite. The reconstructed host phylogeny (see Figure S2), although partially unresolved, agrees with published results on murine phylogenetics $[5,6,48]$. Individual phylogenetic distances are given in Table 4. 


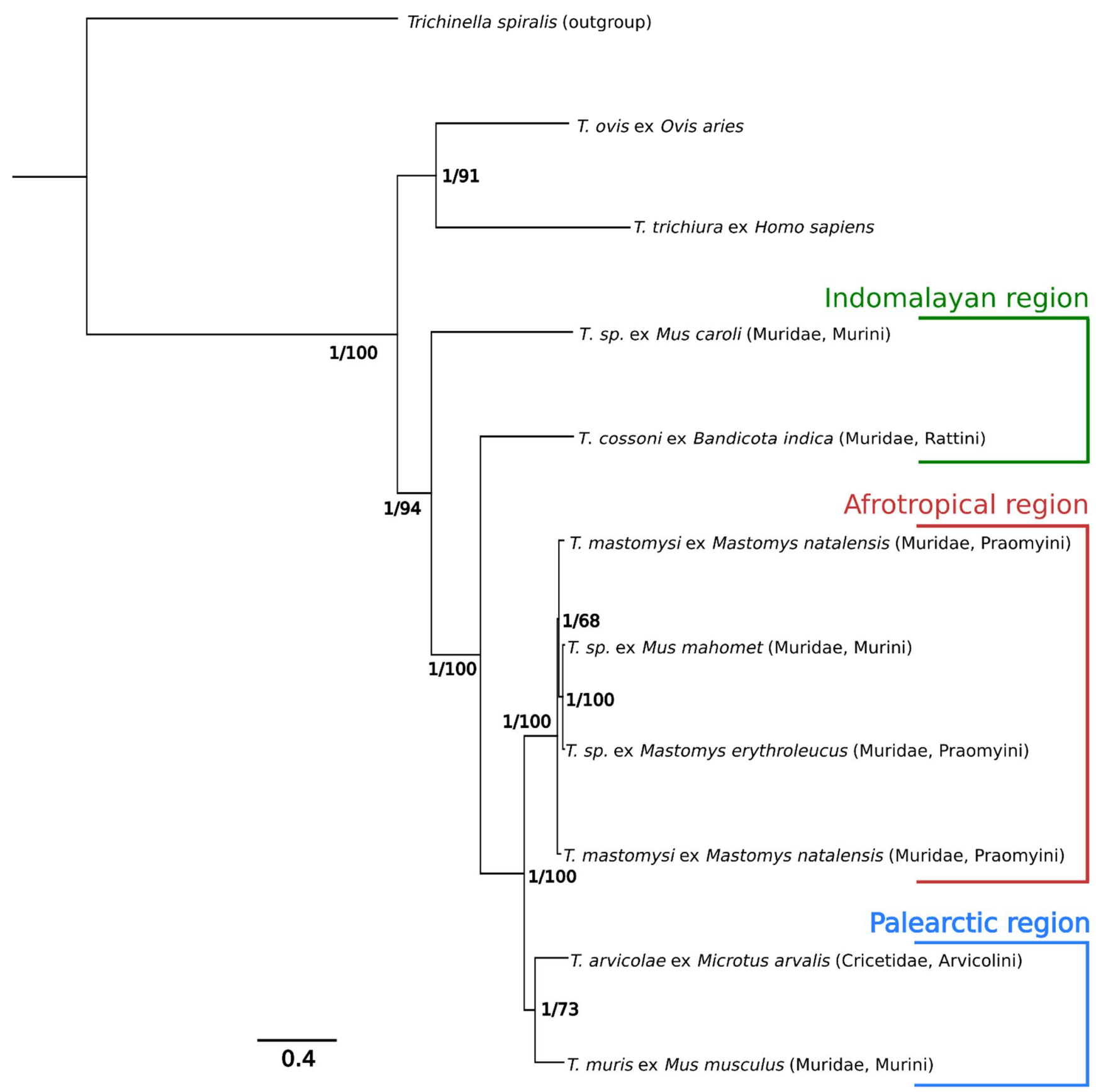

Figure 4. Phylogenetic tree based on whole mitogenome alignment of all Trichuris samples used in our study, with the addition of T. trichiura and T. ovis. Trichinella spiralis used as an outgroup. The node labels denote Bayesian posterior probabilities (BPP) followed by ML bootstrap values. 
Table 4. Phylogenetic distance matrix of all samples used in the Bayesian inference analysis excluding the outgroup sequence of Trichinella spiralis.

\begin{tabular}{|c|c|c|c|c|c|c|c|c|c|c|}
\hline & $\begin{array}{l}\text { T. sp. ex } \\
\text { M. caroli }\end{array}$ & $\begin{array}{l}\text { T. mas- } \\
\text { tomysi }\end{array}$ & $\begin{array}{c}\text { T. sp. ex } \\
P . \\
\text { missonei }\end{array}$ & $\begin{array}{c}\text { T. sp. ex } \\
\text { M. } \\
\text { mahomet }\end{array}$ & $\begin{array}{c}\text { T. sp. ex } \\
\text { M. ery- } \\
\text { throleucus }\end{array}$ & $\begin{array}{l}\text { T. arvi- } \\
\text { colae }\end{array}$ & $\begin{array}{c}\text { T. } \\
\text { muris }\end{array}$ & $\begin{array}{l}\text { T. cos- } \\
\text { soni }\end{array}$ & $\begin{array}{c}T . \\
\text { ovis }\end{array}$ & $\begin{array}{c}T . \\
\text { trichiura }\end{array}$ \\
\hline $\begin{array}{c}\text { T. sp. ex M. } \\
\text { caroli }\end{array}$ & & 33.19 & 33.33 & 33.43 & 33.46 & 32.66 & 33.14 & 34.48 & 36.8 & 38.52 \\
\hline T. mastomysi & 33.19 & & 5.09 & 5.35 & 5.4 & 19.85 & 19.92 & 29.21 & 35.46 & 37.61 \\
\hline $\begin{array}{l}\text { T. sp. ex } P \text {. } \\
\text { missonei }\end{array}$ & 33.33 & 5.09 & & 5.21 & 5.14 & 19.84 & 20.01 & 29.06 & 35.55 & 37.8 \\
\hline $\begin{array}{c}\text { T. sp. ex M. } \\
\text { mahomet }\end{array}$ & 33.43 & 5.34 & 5.21 & & 2.16 & 20.1 & 19.94 & 29.28 & 35.65 & 37.96 \\
\hline $\begin{array}{c}\text { T. sp. ex } M . \\
\text { erythroleucus }\end{array}$ & 33.46 & 5.4 & 5.14 & 2.16 & & 20.21 & 19.96 & 29.2 & 35.62 & 37.96 \\
\hline T. arvicolae & 32.66 & 19.85 & 19.84 & 20.1 & 20.21 & & 17.72 & 28.34 & 35.17 & 37.34 \\
\hline T. muris & 33.14 & 19.92 & 20.01 & 19.94 & 19.96 & 17.72 & & 28.99 & 35.55 & 37.42 \\
\hline T. cossoni & 34.48 & 29.21 & 29.06 & 29.28 & 29.2 & 28.34 & 28.99 & & 37.2 & 38.48 \\
\hline T. ovis & 36.8 & 35.46 & 35.55 & 35.65 & 35.62 & 35.17 & 35.55 & 37.2 & & 36.72 \\
\hline T. trichiura & 38.52 & 37.61 & 37.8 & 37.96 & 37.96 & 37.34 & 37.42 & 38.48 & 36.72 & \\
\hline
\end{tabular}

\section{Discussion}

We have described seven mitochondrial genomes from different rodent whipworms. Two genomes were described completely, while in five others, the information about NCR$\mathrm{L}$ is lacking. The divergence between the genomes was substantial (average pairwise divergence of $21.7 \%$ ). The gene organisation was identical in all samples and did not differ from that of Trichuris found in other animals. The missing tRNA-Lys sequence in T. cossoni was a result of sequencing issues, and there is no reason to suspect that the gene itself is not present within the said mitogenome. GC content did not differ drastically across the samples (Figure 2), and the degree of genome conservation (Figure 3) is in line with other studies, with rRNA subunits being relatively the most conserved region [16,17].

Previously, a high degree of amino-acid divergence between different Trichuris species was reported $[16,17]$ relatively to other nematodes. In accord with these findings, we observed a similar pattern, with mean pairwise amino-acid divergence at the least conserved gene (ATP8) being $38 \%$, which is similar to the reported divergence between T. ovis and T. discolor (33.9\%). When the samples Trichuris ex Mus caroli and Trichuris ex Bandicota indica were excluded from the comparison, this number dropped to $18.1 \%$, as these two samples are the most distinct of the whole dataset. However, this number is still high, since a divergence of around $10 \%$ is common between different nematode species, such as in the genera Ancylostoma with around 4\% [19,20] or Toxocara spp. with around $5-7 \%$ [21]. We suggest these observations are likely not the result of an unusually high mtDNA substitution rates within the Trichuris genus but rather due to sparse sampling from deep mitogenome phylogeny. Given that enoplids are a group that diverged early in the evolution of Nematoda, e.g., the related genus Trichinella diverged from other Nematoda as early as 275 million years ago [49,50], it is probable that the reported amino-acid divergences are a function of deep time: whipworms are likely also an early diverging nematode clade. If so, whipworms may contain a great cryptic biodiversity only starting to be discovered, which is suggested by the recent studies as well as by our own data. Extrapolating from previous studies that compared the amino-acid differences between Trichuris species $[16,51]$, the pairwise amino acid divergences we observe would suggest four of our seven mitogenomes comes from different whipworm species. A fifth taxon of whipworms from African murid genera Mastomys and Mus rodents is also clear. The issue of species delimitation within this taxon will be returned to below.

Our results also support a clear geographic pattern of differentiation between different whipworm lineages, with no evidence of co-divergence between the hosts and parasites in question. The samples clustered together based on the continent/area of their origin: 
the two samples from Ethiopia, although sampled from the Murini and Praomyini tribes, cluster together before clustering with two other Trichuris samples from the Praomyini tribe from Tanzania and Kenya. Similarly, T. arvicolae from a Cricetidae rodent host clusters first with T. muris found in Apodemus sylvaticus, Mus musculus, or Rattus rattus in Europe [2,52], those hosts belonging to the Murini and Rattini tribes of the Muridae family. This pattern might be expected in parasites without strict host specificity. The samples from Asian rodents (Mus caroli and Bandicota indica) did not form a single monophyletic group. In fact, Trichuris genomes obtained from these two samples were the most distinct pair over all the studied samples (pairwise phylogenetic divergence being $34.5 \%$ ), strongly suggesting an existence of two distinct Trichuris haplogroups in Southeast Asia. This is in line with recent results of Ribas et al. [12], which showed that Trichuris from Asian rodents are distinct from the population of European Trichuris based on morphological and genetic characteristics. Our phylogenetic analysis, while only preliminary, also hints at Southeast Asia as a possible evolutionary origin of murine Trichuris, as the samples obtained there both clustered basally and were as distinct from each other as they were from the samples from Africa and Europe.

Our study also has potential implications for the question of species delineation. In our phylogenetic analysis, we used two recognized species, T. muris and T. arvicolae (described on the basis of morphological differences), with $17.7 \%$ sequence divergence. Yet several other samples, such as T. cossoni ex Bandicota indica or Mus caroli, were in fact more divergent from any other sample than the aforementioned figure. The average distance of Trichuris ex M. caroli and B. indica to other murine samples was $33.4 \%$ and $29.8 \%$, respectively (see Table 3 for more details). These numbers are similar to the phylogenetic distance between two recognized and distinct species, T. muris and T. ovis, which in the same analysis amounts to $35.4 \%$. This is in line with results obtained by Liu et al. [16], who found that the genome divergence between T. ovis and T. discolor was $21.9 \%$. If one were to go by the average distance between recognized Trichuris species, one ought to already recognize some of our samples as a putative species.

Returning to the African rodent-host samples: We can state that our observations for samples obtained from species Mastomys natalensis, Mastomys erythroleucus, Praomys missonei, and Mus mahomet are consistent with them all belonging to a single species: Trichuris mastomysi. These samples not only formed a monophyletic haplogroup in our phylogenetic analysis, but they also exhibit low mean pairwise distance $(4.7 \%)$, while being strongly distinct from all other samples (Figure 4). It should be emphasized this consistency does not preclude the three samples being representatives of more than one species. The answer to that question depends on how species are defined. Most species definitions would require data from more than one locus to resolve species-hood (the mitogenome is assumed to comprise a single non-recombining locus). Trichuris mastomysi has been already reported on another species than Mastomys natalensis, namely Mastomys erythroleucus in Western Africa [53]. In this study, T. mastomysi was described as clade II, while another clade, clade I, grouped together Trichuris individuals found in three species of the genus Mastomys (M. natalensis, M. erythroleucus, and M. huberti), Arvicanthis niloticus, and Gerbilliscus gambianus. The genetic distance separating clades I and II was $7.5 \%$ based on the nuclear ITS-1,5.8S and ITS- 2 rDNA genes, suggesting clade I corresponds to individuals belonging to a different Trichuris species than T. mastomysi. It thus appears that, whatever T. mastomysi or Trichuris clade I, both species have the ability to infect several related murid-host species. Nevertheless, it cannot be conclusively ruled out that M. natalensis is the main host of both Trichuris species and the other hosts are just the result of spillovers and thus accidental in nature. There are two important considerations regarding this issue. First, there has never been a systematic investigation into Trichuris on the aforementioned species, so the expected prevalence in African rodents studied here is unknown. Second, the more rodent species T. mastomysi is found to inhabit, the more likely are two specific scenarios. Either T. mastomysi naturally occurs in multiple related rodent species and can infect these without difficulty, or it is particularly prone to spillover 
events. More systematic research into prevalence of T. mastomysi in different rodent species is needed before this question can be satisfactorily answered.

\section{Conclusions}

In the present study, we described seven new mitogenomes of rodent Trichuris representing four different species and analysed their phylogenetic relationships. It would be interesting to get additional material of Trichuris ex Mus caroli to check if morphological characters, generally in males, support the large genetic divergence observed at the mitochondrial level. The large divergence between our Trichuris species coming from three major biogeographic zones in the evolutionary history of the Muridae provides an important source of information for mitochondrial markers to be used as basis for subsequent rodent-borne Trichuris phylogenetic, phylogeographic, and population genetic studies.

Supplementary Materials: The following are available online at https: / www.mdpi.com/article / 10.3390/life11060540/s1, Table S1: Genome organisation of the incomplete mitogenomes; Figure S1: Pairwise comparison of branch lengths between each sample pair as constructed by the maximum likelihood and Bayesian inference phylogenetic analyses. The black line denotes equality; the red dashed line is the regression line from the linear model. The regression slope is equal to 1.06, while the intercept is equal to -0.05 ; Figure S2: Phylogenetic tree of rodent hosts based on CYTB alignment. The node labels denote Bayesian posterior probabilities (BPP).

Author Contributions: Conceptualization, J.G.d.B., A.R. and J.P.; methodology, J.P. and J.G.d.B.; software, J.P.; formal analysis, J.P.; investigation, J.P., J.G.d.B. and A.R.; writing-original draft preparation, J.P.; writing-review and editing, J.G.d.B. and A.R.; visualization, J.P.; supervision, J.G.d.B.; funding acquisition, J.G.d.B. All authors have read and agreed to the published version of the manuscript.

Funding: This study was supported by the project no. 18-19629S of the Czech Science Foundation. The publication fees were covered by project MUNI/A/1581/2020 of Masaryk University, Brno, Czech Republic.

Institutional Review Board Statement: Not applicable.

Informed Consent Statement: Not applicable.

Data Availability Statement: The data presented in this study are openly available in GenBank database (GenBank accession nos. MZ222133-MZ222134 and MZ229684-MZ229690).

Acknowledgments: Computational resources were supplied by the project "e-Infrastruktura CZ" (e-INFRA LM2018140) provided within the program Projects of Large Research, Development, and Innovations Infrastructures. We thank our numerous colleagues who participated to the rodent collections in Tanzania, Kenya, Ethiopia, Laos, and the Czech Republic and in particular J. Bryja, R. Šumbera, Y. Meheretu, A. Katakweba, and S. Morand. We warmly thank A. Bryjová and D. Čížková for lab assistance for the library preparation step and S.J.E Baird for English proofreading of the final version of the manuscript.

Conflicts of Interest: The authors declare no conflict of interest.

\section{References}

1. Ghai, R.R.; Simons, N.D.; Chapman, C.A.; Omeja, P.A.; Davies, T.J.; Ting, N.; Goldberg, T.L. Hidden population structure and cross-species transmission of whipworms (Trichuris sp.) in humans and non human primates in Uganda. PLoS Negl. Trop. Dis. 2014, 8, e3256. [CrossRef] [PubMed]

2. Wasimuddin, J.B.; Ribas, A.; Baird, S.J.; Piálek, J.; Goüy de Bellocq, J. Testing parasite Intimacy: The whipworm Trichuris muris in the European house mouse hybrid zone. Ecol. Evol. 2016, 6, 2688-2701. [CrossRef] [PubMed]

3. Fenwick, A. The global burden of neglected tropical diseases. Public Health 2012, 126, 233-236. [CrossRef]

4. Musser, G.; Carleton, M. Superfamily Muroidea. In Mammal Species of the World. A Taxonomic and Geographic Reference, 3rd ed.; Wilson, D., Reeder, D., Eds.; Johns Hopkins University Press: Baltimore, MD, USA, 2005; Volume 2, pp. 894-1531.

5. Schenk, J.J.; Rowe, K.C.; Steppan, S.J. Ecological opportunity and incumbency in the diversification of repeated continental colonizations by muroid rodents. Syst. Biol. 2013, 62, 837-864. [CrossRef] [PubMed] 
6. Aghová, T.; Kimura, Y.; Bryja, J.; Dobigny, G.; Granjon, L.; Kergoat, G.J. Fossils know it best: Using a new set of fossil calibrations to improve the temporal phylogenetic framework of murid rodents (Rodentia: Muridae). Mol. Phylogenet. Evol. 2018, 128, 98-111. [CrossRef]

7. Petružela, J.; Bryja, J.; Bryjová, A.; Katakweba, A.; Sabuni, C.; Baird, S.J.; Goüy de Bellocq, J. Evolutionary history of Pneumocystis fungi in their African rodent hosts. Inf. Genet. Evol. 2019, 75, 103934. [CrossRef]

8. Latinne, A.; Bezé, F.; Delhaes, L.; Pottier, M.; Gantois, N.; Nguyen, J.; Blasdell, K.; Dei-Cas, E.; Morand, S.; Chabé, M. Genetic diversity and evolution of Pneumocystis fungi infecting wild Southeast Asian murid rodents. Parasitology 2018, 145, 885-900. [CrossRef]

9. Baird, S.J.; Ribas, A.; Macholán, M.; Albrecht, T.; Piálek, J.; Goüy de Bellocq, J. Where are the wormy mice? A reexamination of hybrid parasitism in the European house mouse hybrid zone. Evolution 2012, 66, 2757-2772. [CrossRef] [PubMed]

10. Ribas, A.; López, S.; Makundi, R.H.; Leirs, H.; Goüy de Bellocq, J. Trichuris spp. (Nematoda: Trichuridae) from two rodents, Mastomys natalensis and Gerbilliscus vicinus in Tanzania. J. Parasitol. 2013, 99, 868-875. [CrossRef]

11. Brouat, C.; Duplantier, J.M. Host habitat patchiness and the distance decay of similarity among gastro-intestinal nematode communities in two species of Mastomys (southeastern Senegal). Oecologia 2007, 152, 715-720. [CrossRef] [PubMed]

12. Ribas, A.; Wells, K.; Morand, S.; Chaisiri, K.; Agatsuma, T.; Lakim, M.B.; Yuh Tuh, F.Y.; Saijuntha, W. Whipworms of south-east Asian rodents are distinct from Trichuris muris. Parasitol. Int. 2020, 77, 102128. [CrossRef] [PubMed]

13. Glover, M.; Colombo, S.A.; Thornton, D.J.; Grencis, R.K. Trickle infection and immunity to Trichuris muris. PLoS Pathog. 2019, 15, e1007926. [CrossRef] [PubMed]

14. Foth, B.J.; Tsai, I.J.; Reid, A.J.; Bancroft, A.J.; Nichol, S.; Tracey, A.; Holroyd, N.; Cotton, J.A.; Stanley, E.J.; Zarowiecki, M.; et al. Whipworm genome and dual-species transcriptome analyses provide molecular insights into an intimate host-parasite interaction. Nat. Genet. 2014, 46, 693-700. [CrossRef]

15. Jex, A.R.; Nejsum, P.; Schwarz, E.M.; Hu, L.; Young, N.D.; Hall, R.S.; Korhonen, P.K.; Liao, S.; Thamsborg, S.; Xia, J.; et al. Genome and transcriptome of the porcine whipworm Trichuris suis. Nat. Genet. 2014, 46, 701-706. [CrossRef]

16. Liu, G.H.; Wang, Y.; Xu, M.J.; Zhou, D.H.; Ye, Y.G.; Li, J.Y.; Song, H.Q.; Lin, R.Q.; Zhu, X.Q. Characterization of the complete mitochondrial genomes of two whipworms Trichuris ovis and Trichuris discolor (Nematoda: Trichuridae). Inf. Genet. Evol. 2012, 12, 1635-1641. [CrossRef]

17. Hawash, M.B.; Andersen, L.O.; Gasser, R.B.; Stensvold, C.R.; Nejsum, P. Mitochondrial genome analyses suggest multiple Trichuris species in humans, baboons, and pigs from different geographical regions. PLoS Neglect. Trop. Dis. 2015, 9, e0004059. [CrossRef]

18. Holroyd, N.; Kikuchi, T.; Berriman, M. Genome, Transcriptome and Proteome Adaptations to Nematode Parasitism in Strongyloides, Direct Genbank Submission, NC_028621. 2020. Available online: https://www.ncbi.nlm.nih.gov/nucleotide/NC_028621.1 (accessed on 15 January 2021).

19. Jex, A.R.; Waeschenbach, A.; Hu, M.; Van Wyk, J.A.; Beveridge, I.; Littlewood, D.T.J.; Gasser, R.B. The mitochondrial genomes of Ancylostoma caninum and Bunostomum phlebotomum-Two hookworms of animal health and zoonotic importance. BMC Genom. 2009, 10, 79. [CrossRef]

20. $\mathrm{Hu}, \mathrm{M}$.; Chilton, N.B.; Gasser, R.B. The mitochondrial genomes of the human hookworms, Ancylostoma duodenale and Necator americanus (Nematoda: Secernentea). Int. J. Parasitol. 2002, 32, 145-158. [CrossRef]

21. Li, M.W.; Lin, R.Q.; Song, H.Q.; Wu, X.Y.; Zhu, X.Q. The complete mitochondrial genomes for three Toxocara species of human and animal health significance. BMC Genom. 2008, 9, 224. [CrossRef]

22. Kern, E.; Kim, T.; Park, J.K. The mitochondrial genome in nematode phylogenetics. Front. Ecol. Evol. 2020, 8, 250. [CrossRef]

23. Cutillas, C.; Callejon, R.; De Rojas, M.; Tewes, B.; Ubeda, J.M.; Ariza, C.; Guevara, D.C. Trichuris suis and Trichuris trichiura are different nematode species. Acta Trop. 2009, 111, 299-307. [CrossRef] [PubMed]

24. Feliu, C.; Spakulová, M.; Casanova, J.C.; Renaud, F.; Morand, S.; Hugot, J.P.; Santala, P.; Durand, P. Genetic and morphological heterogeneity in small rodent whipworms in southwestern Europe: Characterization of Trichuris muris and description of Trichuris arvicolae n. sp. (Nematoda: Trichuridae). J. Parasitol. 2000, 86, 442-449. [CrossRef]

25. Eberhardt, A.T.; del Rosario Robles, M.; Monje, L.D.; Beldomenico, P.M.; Callejón, R. A new Trichuris species (Nematoda: Trichuridae) from capybaras: Morphological-molecular characterization and phylogenetic relationships. Acta Trop. 2019, 190, 244-252. [CrossRef] [PubMed]

26. Callejón, R.; Cutillas, C.; Nadler, S.A. Nuclear and mitochondrial genes for inferring Trichuris phylogeny. Parasitol. Res. 2015, 114, 4591-4599. [CrossRef]

27. Rivero, J.; Callejón, R.; Cutillas, C. Complete Mitochondrial Genome of Trichuris trichiura from Macaca sylvanus and Papio papio. Life 2021, 11, 126. [CrossRef]

28. Verster, A. Trichuris species from South African rodents and a hyracoid. Onderstepoort J. Vet. Res. 1960, $28,465-471$.

29. Těšíková, J.; Bryjová, A.; Bryja, J.; Lavrenchenko, L.A.; Goüy de Bellocq, J. Hantavirus strains in East Africa related to Western African hantaviruses. Vector-Borne Zoonot Dis. 2017, 17, 278-280. [CrossRef]

30. Lecompte, É.; Granjon, L.; Peterhans, J.K.; Denys, C. Cytochrome b-based phylogeny of the Praomys group (Rodentia, Murinae): A new African radiation? Comptes Rendus Biol. 2002, 325, 827-840. [CrossRef] 
31. Cuypers, L.N.; Baird, S.J.; Hánová, A.; Locus, T.; Katakweba, A.S.; Gryseels, S.; Bryja, J.; Leirs, H.; Goüy de Bellocq, J. Three arenaviruses in three subspecific natal multimammate mouse taxa in Tanzania: Same host specificity, but different spatial genetic structure? Virus Evol. 2020, 6, veaa039. [CrossRef] [PubMed]

32. Andrews, S. FastQC: A Quality Control Tool for High Throughput Sequence Data, Babraham Bioinformatics. 2010. Available online: https:/ / www.bioinformatics.babraham.ac.uk/projects/fastqc/ (accessed on 15 January 2021).

33. Jiang, H.; Lei, R.; Ding, S.W.; Zhu, S. Skewer: A fast and accurate adapter trimmer for next-generation sequencing paired-end reads. BMC Bioinform. 2014, 15, 182. [CrossRef]

34. Bankevich, A.; Nurk, S.; Antipov, D.; Gurevich, A.A.; Dvorkin, M.; Kulikov, A.S.; Lesin, V.M.; Nikolenko, S.I.; Pham, S.; Prjibelski, A.D.; et al. SPAdes: A new genome assembly algorithm and its applications to single-cell sequencing. J. Comput. Biol. 2012, 19, 455-477. [CrossRef]

35. Buchfink, B.; Xie, C.; Huson, D.H. Fast and sensitive protein alignment using DIAMOND. Nat. Methods 2015, 12, 59-60. [CrossRef]

36. Altschul, S.F.; Gish, W.; Miller, W.; Myers, E.W.; Lipman, D.J. Basic local alignment search tool. J. Mol. Biol. 1990, 215, 403-410. [CrossRef]

37. Laetsch, D.R.; Blaxter, M.L. BlobTools: Interrogation of genome assemblies. F1000Research 2017, 6, 1287. [CrossRef]

38. Darling, A.C.E.; Mau, B.; Blattner, F.R.; Perna, N.T. Mauve: Multiple alignment of conserved genomic sequence with rearrangements. Genome Res. 2004, 14, 1394-1403. [CrossRef]

39. Laslett, D.; Canbäck, B. ARWEN: A program to detect tRNA genes in metazoan mitochondrial nucleotide sequences. Bioinformatics 2008, 24, 172-175. [CrossRef] [PubMed]

40. Bernt, M.; Donath, A.; Jühling, F.; Externbrink, F.; Florentz, C.; Fritzsch, G.; Pütz, J.; Middendorf, M.; Stadler, P.F. MITOS: Improved de novo metazoan mitochondrial genome annotation. Mol. Phylogenet. Evol. 2013, 69, 313-319. [CrossRef] [PubMed]

41. Python Software Foundation. Python Language Reference, Version 3.6. Available online: http://www.python.org (accessed on 15 January 2021).

42. Cock, P.J.; Antao, T.; Chang, J.T.; Chapman, B.A.; Cox, C.J.; Dalke, A.; Friedgerg, I.; Hamelryck, T.; Kauff, F.; Wilczynski, B.; et al. Biopython: Freely available Python tools for computational molecular biology and bioinformatics. Bioinformatics 2009, 25, 1422-1423. [CrossRef]

43. Harris, C.R.; Millman, K.J.; van der Walt, S.J.; Gommers, R.; Virtanen, P.; Cournapeau, D.; Wieser, E.; Taylor, J.; Berg, S.; Smith, N.J.; et al. Array programming with NumPy. Nature 2020, 585, 357-362. [CrossRef]

44. Hunter, J.D. Matplotlib: A 2D graphics environment. IEEE Ann. Hist. Comput. 2007, 9, 90-95. [CrossRef]

45. Darriba, D.; Taboada, G.L.; Doallo, R.; Posada, D. jModelTest 2: More models, new heuristics and parallel computing. Nat. Methods 2012, 9, 772. [CrossRef]

46. Ronquist, F.; Teslenko, M.; Van Der Mark, P.; Ayres, D.L.; Darling, A.; Höhna, S.; Larget, B.; Liu, L.; Suchard, M.A.; Huelsenbeck, J.P. MrBayes 3.2: Efficient Bayesian phylogenetic inference and model choice across a large model space. Syst. Biol. 2012, 61, 539-542. [CrossRef]

47. Stamatakis, A. RAxML version 8: A tool for phylogenetic analysis and post-analysis of large phylogenies. Bioinformatics 2014, 30, 1312-1313. [CrossRef]

48. Steppan, S.J.; Schenk, J.J. Muroid rodent phylogenetics: 900-species tree reveals increasing diversification rates. PLoS ONE 2017, 12, e0183070. [CrossRef] [PubMed]

49. Zarlenga, D.S.; Rosenthal, B.M.; La Rosa, G.; Pozio, E.; Hoberg, E.P. Post-Miocene expansion, colonization, and host switching drove speciation among extant nematodes of the archaic genus Trichinella. Proc. Natl. Acad. Sci. USA 2006, 103, 7354-7359. [CrossRef]

50. Mitreva, M.; Jasmer, D.P.; Zarlenga, D.S.; Wang, Z.; Abubucker, S.; Martin, J.; Taylor, C.M.; Yin, Y.; Fulton, L.; Minx, P.; et al. The draft genome of the parasitic nematode Trichinella spiralis. Nat. Genet. 2011, 43, 228-235. [CrossRef] [PubMed]

51. Blouin, M.S. Molecular prospecting for cryptic species of nematodes: Mitochondrial DNA versus internal transcribed spacer. Int. J. Parasitol. 2002, 32, 527-531. [CrossRef]

52. Callejón, R.; de Rojas, M.; Nieberding, C.; Foronda, P.; Feliú, C.; Guevara, D.; Cutillas, C. Molecular evolution of Trichuris muris isolated from different Muridae hosts in Europe. Parasitol. Res. 2010, 107, 631-641. [CrossRef]

53. Ribas, A.; Diagne, C.; Tatard, C.; Diallo, M.; Poonlaphdecha, S.; Brouat, C. Whipworm diversity in West African rodents: A molecular approach and the description of Trichuris duplantieri n. sp.(Nematoda: Trichuridae). Parasitol. Res. 2017, 116, 1265-1271. [CrossRef] [PubMed] 